\title{
Pancasila sebagai Dasar Pembangunan Hukum Di Indonesia
}

\author{
Oleh : Any Ismayawati \\ e-mail : any.ismayawati@yahoo.com
}

\begin{abstract}
This paper aims to examine the urgency of Pancasila in the National Law Development Therefore, why Pancasila should be guided in every formation of law in Indonesia. How does the philosophical foundation of Pancasila use as a guide in the development of national law and what its juridical basis.

Pancasila is the ideology of the Indonesian nation, is a crystallization of the noble values of the Indonesian nation derived from religious values and customary values, believed to be true, and became the basis and guidance of the behavior of the Indonesian nation in the life, nation and state. Based on that, Pancasila becomes the philosophical foundation of the development of national law because the law can be enforced and effective if the law is based on religious values, customs values and state law. In addition, the foundation of the Pancasila state is the source of all sources of law in Indonesia so that it becomes the necessity of Pancasila as the philosophical foundation in the development of law in Indonesia.

the legal basis for the use of Pancasila as the foundation / guideline in the development of national law is included in Law Number 10 of 2004 on the Establishment of Legislation which is later enhanced by Law Number 12 Year 2011 on the Establishment of Laws and Regulations. In Article 2 of Law Number 12 of 2011 explicitly stated that Pancasila is the source of all sources of law. the contents of Article 2 implies that in the formation of any legislation should not conflict with the values contained in the principles of Pancasila
\end{abstract}

Key Words: Development of National Law, Pancasila, philosophical foundation, juridical foundation 


\section{A. Latar Belakang}

Pembangunan hukum yang berkelanjutan merupakan kebutuhan yang harus dilakukan oleh suatu bangsa dalam mengikuti perkembangan masyarakat maupun perkembangan kejahatan, karena pada dasarnya perkembangan kejahatan selalu mengikuti perkembangan masyarakat itu sendiri. Menurut Barda Nawawi Arief bahwa pembangunan hukum harus selalu disesuaikan dengan dinamika kehidupan (Roeslan Saleh, 1984: 41). Dalam konteks inilah pengkajian terhadap pembaharuan hukum merupakan kajian yang bergenerasi (Barda Nawawi Arief, 2009: 2). Lebih lanjut, bahwa pembaharuan/pembangunan hukum pada hakikatnya merupakan pembaharuan/pembangunan yang berkelanjutan (sustainable reform/sustainable development) (Barda Nawawi Arief ,1994:15/ Jay A. Sigler ,1981:269). Menurut M. Mahfud MD Produk hukum senantiasa berubah dan diubah sesuai dengan perkembangan zaman dan perubahan masyarakat karena hukum itu tidak berada pada situasi vakum. Dengan demikian dapat juga dikatakan bahwa hukum sebagai pelayan kebutuhan masyarakat harus diperbaharui agar aktual dengan kebutuhan masyarakat yang dilayani (M. Mahfud MD: 2006). Pernyataan-pernyataan tersebut menunjukkan bahwa hukum selalu dalam proses untuk menjadi karena hukum itu bergerak.

Dalam melakukan pembangunan hukum diperlukan suatu pedoman agar pembangunan hukum tersebut dapat mendukung tercapainya tujuan nasional. Pembaharuan Sistem Hukum Nasional yang selama ini ingin diwujudkan adalah Sistem Hukum Nasional ber-Pancasila. Menurut Sudarto, Dijelaskan bahwa negara Indonesia dalam melaksanakan politik hukumnya berlandaskan dasar filsafat Negara ialah Pancasila dan UUD 1945 (Sudarto,1983:20/ Moeljatno, 1985:14). Satjipto Rahardjo mengemukakan bahwa Filsafat Pancasila, beserta tujuan yang tercantum dalam Pembukaan UUD 1945 menjadi kerangka acuan pembinaan tata hukum yang baru (Satjipto Rahardjo, 2009:9). Di dalam Pancasila terkandung nilai-nilai religius, humanistik maupun demokratis. Menurut Ismail Saleh, bahwa dengan dijadikannya Pancasila sebagai dasar dalam pembangunan sistem hukum nasional, maka di dalam 
sistem hukum Indonesia tidak boleh ada pertentangan nilai antara hukum tertulis dan hukum tidak tertulis (Ismail Saleh,1987:38). Untuk itu di dalam melakukan pembaharuan/pembangunan Sistem Hukum Nasional dicantumkan rambu-rambu sebagaimana yang tertuang dalam Undang-undang Nomer 17 Tahun 2007 tentang Rencana Pembangunan Jangka Panjang Nasional (RPJPN) tahun 2005-2025, dalam Bab IV.1.3 tentang Arah Pembangunan Jangka Panjang tahun 2005-2025, dan dalam uraian dari misi kedua RPJP tersebut.

Dalam uraian misi kedua RPJPN antara lain dikemukakan bahwa: "Pembangunan materi hukum diarahkan untuk melanjutkan pembaruan produk hukum untuk menggantikan peraturan perundang-undangan warisan kolonial yang mencerminkan nilai-nilai sosial dan kepentingan masyarakat Indonesia serta mampu mendorong tumbuhnya kreativitas dan pelibatan masyarakat yang sangat dibutuhkan untuk mendukung pelaksanaan penyelenggaraan pemerintahan dan pembangunan nasional yang bersumber pada Pancasila dan UUD 1945, yang mencakup perencanaan hukum, pembentukan hukum, penelitian dan pengembangan hukum". Berdasarkan ketentuan tersebut maka sesungguhnya menjadi suatu keniscayaan bahwa dalam pembangunan/pembaharuan hukum, Pancasila harus menjadi sumber nilai dan landasan dalam kerangka berpikir.Dalam konteks ini maka semua produk hukum Indonesia harus didasarkan pada pokok pikiran yang terkandung dalam Pancasila.

\section{B. Pancasila sebagai Landasan Filosofis Pembangunan Hukum Nasional}

Pancasila dalam kehidupan berbangsa dan bernegara merupakan falsafah serta ideologi bangsa dan negara Indonesia. Nilai-nilaiyang terkandung di dalam Pancasila berasal dari bangsa Indonesia sendiri,yaitu nilai-nilai adat istiadat, kebudayaan dan nilai-nilai religius.Melalui sidang BPUPKI dan PPKI pada tanggal 18 Agustus 1945 Pancasila disahkan sebagai dasar falsafah negara (Philosofische Gronslag) Republik Indonesia. Berdasarkan kedudukan Pancasila tersebut maka Pancasila merupakan suatu dasar nilai serta norma untuk mengatur pemerintah 
negara/penyelenggara negara. Oleh sebab itu, seluruh pelaksanaan dan penyelenggaraan negara terutama peraturan perundang-undangan negara dijabarkan dan diderivikasi dari nilai-nilai Pancasila (M.Ali Mansyur, 2005:3-4). Menurut M.Ali Masyur (2005:6), bahwa Pancasila sebagai dasar negara merupakan falsafah hukum nasional seharusnya mempunyai sifat imperatif, yaitu Pancasila dijadikan dasar dan arah pengembangan falsafah hukum nasional dan menjadi acuan dalam penyusunan, pembinaan dan pengembangan falsafah hukum yang konsisten dan relevan dengan nilai-nilai Pancasila itu sendiri (M.Ali Mansyur, 2005:66). Dari beberapa penjelasan tentang kedudukan Pancasila,menunjukkan bahwa sebagai dasar falsafah negara, Pancasila adalah sebagai sumber segala sumber hukum bagi bangsa Indonesia.

Dikemukakan oleh Soerjanto Poespowardojo (1996:44), bahwa Pancasila adalah Falsafah negara oleh sebab itu Pancasila merupakan nilai dasar yang normatif terhadap seluruh penyelenggaraan Negara Republik Indonesia. Bertolak pada pendapat tersebut maka menjadi keniscayaan bahwa dalam menetapkan suatu peraturan yang menjadi dasar dalam menyelenggarakan kehidupan berbangsa dan bernegara harus menggunakan nilai-nilai Pancasila sebagai landasan filsafati.

Pancasila di samping sebagai dasar falsafah bangsa Indonesia, juga merupakan pandangan hidup bangsa (way of life) bangsa Indonesia, yaitu penunjuk arah semua kegiatan atau aktivitas hidup dan kehidupan di segala bidang. Hal ini berarti bahwa semua tingkah-laku dan tindak-perbuatan setiap manusia Indonesia harus dijiwai dan merupakan pancaran dari semua sila Pancasila, karena Pancasila sebagai weltanschauung selalu merupakan kesatuan, tidak bisa dilepas-pisahkan satu dengan yang lain; keseluruhan sila di dalam Pancasila merupakan satu kesatuan organis (Dardji Darmodihardjo, 2007:210).

Penjelasan yang sama tentang Pancasila sebagai dasar filsafat negara juga dikemukakan Noor MS Bakry (1994:66). Menurutnya, Pancasila pada hakikatnya dibedakan atas dua kelompok, yaitu secara material dan formal. Secara material, Pancasila merupakan filsafat hidup bangsa yang dapat dihayati sebagai jiwa bangsa, kepribadian bangsa, sarana 
tujuan hidup bangsa, pandangan hidup bangsa dan pedoman hidup bangsa. Secara formal Pancasila merupakan dasar filsafat negara, yaitu sebagai sumber dari segala sumber hukum negara Indonesia dan juga sebagai perjanjian luhur bangsa Indonesia dalam bernegara. Demikian pula pendapat yang dikemukakan oleh Notonagoro (2013:3) pada saat pemberian Doctor Honoris Causa kepada Presiden Republik Indonesia Ir. Soekarno, bahwa Pancasila tidak sekedar mempunyai arti dan manfaat dalam memberikan jawaban atas pertanyaan asal negara, sifat negara, tujuan negara,dan tugas bekerjanya negara serta sikap, akan tetapi Pancasila juga merupakan pedoman untuk penentuan sikap dan pemberian bentuk kepada negara yang dapat dipertanggungjawabkan secara ilmu pengetahuan. Dalam hal ini Pancasila secara ilmiah merupakan pedoman dalam berbangsa dan bernegara bagi masyarakat Indonesia.

Bertolak pada pandangan bahwa Pancasila merupakan pedoman dalam kehidupan berbangsa dan bernegara maka dikatakan oleh Mubyarto (2013:3), bahwa semua orang yang berada di Indonesia, harus menyesuaikan diri dan melaksanakan asas Pancasila di semua bidang kehidupan. Secara implisit pendapat Mubyarto tersebut mengatakan bahwa Pancasila merupakan sumber segala sumber hukum yang mengatur tata kehidupan berbangsa dan bernegara bagi seluruh bangsa Indonesia.

Pancasila sebagai pandangan hidup bangsa terdiri atas suatu rangkaian nilai-nilai luhur yang merupakan suatu wawasan menyeluruh terhadap kehidupan itu sendiri. Sebagai pandangan hidup, Pancasila berfungsi sebagai kerangka acuan untuk menata kehidupan diri pribadi maupun dalam interaksi antar manusia di masyarakat serta alam sekitarnya. Di samping itu, Pancasila berfungsi sebagai penuntun dan penunjuk arah bagi bangsa Indonesia dalam semua kegiatan dan aktivitas hidup serta kehidupan di segala bidang (Darji Darmodiharjo,1991:16-17).

Nilai-nilai dasar bangsa Indonesia yang sudah menjadi pandangan hidup bangsa, terkristalisasi berupa nilai-nilai dalam sila-sila Pancasila, oleh sebab itu Pancasila seharusnya ditempatkan sebagai filter dalam pembangunan hukum untuk menghadapi segala dampak globalisasi sebagai akibat perkembangan IPTEK. Bertolak pada 
pendapat Muladi (2007:30) yang mengatakan bahwa Pancasila merupakan filter dalam mentransformasikan nilainilai global dalam kehidupan nasional karena globalisasi tidak dapat diterima secara bulat, maka dalam mensikapi perkembangan IPTEK penggunaan nilai dalam sila-sila menjadi sangat penting sebagai filter. Sebagaimana yang diketahui bahwadengan perkembangan IPTEK menjadikan dunia tanpa batas, informasi apa pun serta dari mana pun dapat langusng diterima oleh masyarakat Indonesia, sedangkan tidak semua perkembangan dan informasi yang ada dapat diterima atau dapat diterapkan dalam kehidupan bangsa Indonesia.

Dalam kehidupan berbangsa dan bernegara, tidak dapat dinafikkan arti penting perkembangan IPTEK, akan tetapi bukan berarti dalam proses pembangunan - termasuk di dalamnya pembangunan hukum - boleh mengabaikan akar nilai-nilai asli bangsa Indonesia. Dalam proses pembangunan -termasuk pembangunan hukum- diperlukan suatu pedoman dasar agar dapat mengakomodir semua perkembangan masyrakat di satu sisi, dan di sisi lain bangsa ini masih berpijak pada nilai-nilai asli bangsa Indonesia yang sudah menjadi ideologi bangsa dan negara Indonesia yaitu Pancasila. Dalam hal ini keberadaan Pancasila menjadi sangat penting karena sebagai landasan untuk mengatasi berbagai permasalahan sebagai akibat perkembangan IPTEK. Sebagaimana yang dikemukakan oleh Muladi (2007:26-27) bahwa dengan semakin pesatnya perkembangan IPTEK, keberadaan ideologi sangat dibutuhkan karena dampak perkembangan IPTEK dapat menimbulkan komplikasi negatif dalam kehidupan berbangsa dan bernegara.

Terjadinya globalisasi sebagai salah satu dampak ditemukannya internet sangat berpengaruh terhadap perkembangan masyarakat dunia, tak terkecuali masyarakat Indonesia. Perkembangan masyarakat tersebut dengan sendirinya berpengaruh terhadap perkembangan hukum. Sebagaimana yang dikatakan oleh Moeljatno (1985:2) hukum hidup dan tumbuh bersama-sama dengan rakyat. Beliau juga mengutip kalimat dari Presiden Soekarno "bahwa hukum adalah tidak lain dari pada ekspresi cita-cita politik rakyat". Hukum harus mampu mengikuti perkembangan 
masyarakat, meskipun demikian bukan berarti dalam perkembangannya hukum boleh meninggalkan nilai-nilai dasar yang telah menjadi pedoman hidup masyarakat yang bersangkutan. Nilai-nilai dasar tersebut harus tetap menjadi basic idea dalam pembangunan hukum.

Berdasarkan beberapa pendapat tersebut menunjukkan bahwa Ideologi dibutuhkan suatu negara dalam rangka menentukan warna "Political will and morale" dalam menghadapi permasalahan bangsa (Muladi, 2007:34). Salah satu cara untuk menyelesaikan permasalahan bangsa adalah melakukan pembangunan hukum.Dalam pembangunan hukum, Pancasila sebagai ideologi bangsa Indonesia sangat dibutuhkan untuk menenntukan warna "Political will and morale".

Dikatakan oleh Tamanaha (Brian Z.Tamanaha, 2006:4) maupun Eugen Erclich (Endang Sutrisno, 2009:24), bahwa hukum merupakan pencerminan karakter suatu bangsa, maka hukum nasional bangsa Indonesia harus merupakan himpunan nilai-nilai budaya bangsa Indonesia yang tumbuh dan berkembang sejak jaman dahulu sebagi "kearifan lokal". Bertolak pada pendapat tersebut maka Pancasila sebagai ideologi, dasar negara dan falsafah bangsa Indonsia, yang aktualisasinya tercermin dalam berbagai penataan kehidupan dalam arti luas, sudah seharusnya menjadi dasar pembangunan hukum nasional Indonesia, karena sesungguhnya Pancasila adalah "kearifan lokal" bagi bangsa Indonesia (Koento Wibisono Siswomihrdjo :49).

Dalam melakukan pembangunan hukum nasional perlu dilakukan dengan melalui beberapa pendekatan, antara lain pendekatan kebijakan, pendekatan religius dan pendekatan nilai. Berkaitan dengan pendekatan yang berorientasi pada nilai, maka dalam rekonstruksi hukum pidana Indonesia harus bersumber pada ide-ide dasar Pancasila sebagai nilai-nilai dasar dalam berkehidupan dan berkebangsaan bagi bangsa Indonesia (Barda nawawi Arief, 2005:4). Dikemukakan oleh Sudarto (1972: 72). bahwa dalam pembentukan KUHP Nasional (salah satu bentuk pembangunan hukum nasional) harus berasaskan Pancasila. B.Arief Sidharta (2007:149) berpendapat bahwa Pancasila sebagai landasan kefilsafatan dan norma kritik Tata hukum Indonesia, maka dalam melakukan pembangunan hukum 
Indonesia -dalam rangka menyelenggarakan kehidupan berbangsa dan bernegara- harus dijiwai oleh Pancasila. Lebih lanjut dikatakan oleh Barda Nawawi Arief bahwa seyogyanya pembaharuan hukum pidana nasional dilatarbelakangi dan berdasar pada ide-ide dasar (basic ideas) Pancasila. Hal tersebut dikarenakan di dalam Pancasila terkandung keseimbangan nilai, antara lain nilai ketuhanan (moral religius), kemanusiaan (humanistic), kebangsaan, demokrasi, dan keadilan sosial, oleh sebab itu perlu menggali hukum agama dan hukum adat sebagai dasar motivasi, inspirasi bahkan untuk dasar mengevaluasi hukum yang sedang berlaku (Barda Nawawi Arief, 2005: 4-8). Latar belakang yang mendasari pendapat tersebut adalah karena nilai-nilai Pancasila bersumber pada nilai-nilai hukum agama dan hukum adat, dan nilai-nilai tersebut lebih sesuai dengan karakteristik masyarakat Indonesia yang bersifat monodualistik dan pluralistic (Barda Nawawi Arief, 2005: 8).

Keberadaan Pancasila - sial-sila Pancasila - secara jelas dan tegas dietapkan sebagai dasar Negara sebagaimana yang tercantum dalam Pembukaan UUD 1945 alinea IV. Disebutkan dalam alinea tersebut bahwa Negara Republik Indonesia dibentuk dengan berdasarkan pada sila-sila Pancasila. Disebutkan pula bahwa sila-sila Pancasila merupakan sarana atau alat dalam rangka mencapi tujuan nasional. Kalimat dalam alinea IV tersebut mempunyai makna yang sangat dalam dan luas bagi bangsa Indonesia dalam kehidupan berbangsa dan bernegara. Sebagaimana yang dikatakan oleh B. Arief Sidharta (2005: 145) bahwa dengan ditempatkannya Pancasila dalam Pembukaan UUD 1945 maka Pancasila menjadi landasan kefilsafatan yang mendasari dan menjiwai kehidupan kenegaraan di Indonesia.

Apabila dikaji lebih lanjut kalimat dalam alinea IV Pembukaan UUD 1945 terkandung arti bahwa bangsa Indonesia dalam menyelenggarakan kehidupan berbangsa dan bernegara tidak boleh bertentangan atau melanggar nilai-nilai yang ada dalam sila-sila Pancasila. Meminjam pendapat Kaelan (1996:43-44), bahwa dalam alinea IV pembukaan UUD 1945 terkandung arti bahwa Pancasila merupakan dasar filsafat negara yang mengandung 
konsekuensi bahwa semua bidang kehidupan dalam penyelenggaraan negara harus berdasar pada nilai-nilai yang terkandung dalam sila-sila Pancasila.

\section{Landasan Yuridis Penggunaan Pancasila sebagai Dasar Pembanguan Hukum Nasional}

Digunakanya Pancasila sebagai dasar dalam pembentukan perundang-undangan, secara yuridis dapat dilihat dalam Undang-undang Nomor 10 tahun 2004 tentang Pembentukan Peraturan Perundang-undangan yang kermudian disempurnakan dengan Undang-undang Nomor 12 Tahun 2011 tentang Pembentukan Peraturan Perundangundangan. Di dalam Pasal 2 Undang-undang Nomor 12 tahun 2011 Tentang Pembentukan Peraturan Perundangundangan, secara eksplisit disebutkan bahwa Pancasila adalah sumber segala sumber hukum. Bunyi Pasal 2 tersebut mengandung makna bahwa dalam pembentukan peraturan perundangan apapun tidak boleh bertentangan dengan nilai-nilai yang terkandung dalam sila-sila Pancasila.

Bagi bangsa Indonesia pembangunan hukum nasional
perlu dilakukan bukan sekedar untuk mengikuti/menghadapi perkembangan masyarakat, akan tetapi pembangunan hukum nasional harus dilakukan bangsa Indonesia karena hukum yang ada sekarang ini khususnya hukum pidana- sebagian besar adalah peninggalan pemerintah kolonial. Sebagai negara yang merdeka, maka pembangunan hukum yang sesuai dengan dasar negara merupakan suatu keharusan. Keharusan tersebut tertuang dalam konstitusi Negara Indonesia yaitu UUD 1945. Oleh sebab itu pembangunan hukum yang merupakan rangkaian proses dari rule breaking kemudian dilanjutkan dengan rule making mengandung suatu pengertian bahwa yang harus dilakukan dalam pembangunan hukum tidak hanya mengubah teks-teks dari pasal-pasal dalam undang-undang tetapi lebih dari itu mengubah jiwa dari hukum itu sendiri agar sesuai dengan ideologi bangsa Indonesia, yaitu Pancasila.

Pada dasarnya hukum adalah alat untuk mencapai tujuan, oleh sebab itu perlu dibentuk suatu hukum yang dapat mewujudkan tujuan nasional. Adapun tujuan nasional bangsa Indonesia tertuang dalam pembukaan UUD 1945, 
yaitu melindungi segenap bangsa Indonesia dan seluruh tumpah darah Indonesia, memajukan kesejahteraan umum, mencerdaskan kehidupan bangsa, dan ikut melaksanakan ketertiban dunia berdasarkan kemerdekaan, perdamaian abadi, dan keadilan sosial. Tujuan nasional tersebut hanya akan menjadi kata-kata indah yang tidak bermakna apabila tidak ada upaya dan sarana untuk mewujudkannya. Agar tujuan nasional tersebut dapat terwujud maka diperlukan sarana atau alat yang salah satunya berupa regulasi/peraturan dalam semua bidang kehidupan.

Berkaitan dengan tujuan nasional yang merupakan cita-cita seluruh bangsa Indonesia, maka hukum yang digunakan harus sesuai dengan cita-cita dan nilai-nilai bangsa Indonesia, karena hukum yang dapat ditegakkan dan efektif adalah hukum yang sesuai dengan nilai-nilai suatu bangsa. Adapun hukum yang sesuai dengan nilai dan jiwa bangsa Indonesia adalah hukum yang berdasarkan ideologi bangsa Indonesia, karena ideologi adalah kristalisasi nilai-nilai suatu bangsa yang diyakini kebenarannya.

Ideologi bangsa Indonesia adalah Pancasila, maka menjadikan Pancasila sebagai cita hukum adalah suatu keniscayaan. Pancasila dijadikan sebagai sumber dari segala sumber hukum sudah ditetapkan pada saat Indonesia baru merdeka, yaitu sejak sila-sila Pancasila dicantumkan dalam pembukaan UUD 1945 sebagai dasar negara.Melakukan pembaharuan hukum pidana berdasar pada nilai-nilai Pancasila diharapkan akan tercapai keadilan Pancasila, yaitu keadilan yang berketuhanan, keadilan yang berkemanusiaan, keadilan yang demokratik, keadilan yang nasionalistik serta berkeadilan sosial. Keadilan Pancasila yang terwujudkan dalam kategori lima macam keadilan tersebut merupakan wujud keadilan yang sesungguhnya (keadilan substantif), bukan sekedar keadilan formal saja (Barda Nawaawi Arief, 2011:30). Hal tersebut dilandasi pertimbangan bahwa hukum yang ada sekarang hanya melahirkan keadilan formal sehingga perlu diperbaharui agar tujuan hukum untuk mewujudkan keadilan yang sesungguhnya dapat tercapai.

Sebagaimana yang telah dikemukakan di muka bahwa hukum suatu bangsa seharusnya bersumber pada nilai-nilai 
luhur bangsa yang bersangkutan, maka menjadi keharusan pula dalam melakukan rekonstruksi hukum pidana Indonesia agar berdasar pada nilai-nilai yang dimiliki dan diyakini kebenarannya oleh bangsa Indonesia. Hal itu dikarenakan nilai-nilai tersebut memberi warna yang menjadi jati diri bangsa Indonesia yang membedakan dengan bangsa-bangsa lain serta nilai-nilai tersebut dapat mewujudkan keadilan yang lebih sesuai dengan keinginan bangsa Indonesia. Nilai-nilai luhur bangsa Indonesia tersebut sebagaimana yang kita ketahui, terkristalisasi dalam wujud ideologi, dasar falsafah dan pedoman hidup bangsa Indonesia, yaitu Pancasila. Oleh sebab itu harus difahami untuk kemudian dilaksanakan bahawa Pancasila merupakan dasar pembangunan hokum nasional, harus berdasar pada nilai-nilai yang terkandung dalam sila-sila Pancasila.

Nilai-nilai dasar bangsa Indonesia yang sudah menjadi pandangan hidup bangsa, terkristalisasi berupa nilai-nilai dalam sila-sila Pancasila, oleh sebab itu Pancasila seharusnya ditempatkan sebagai filter dalam pembangunan hukum untuk menghadapi segala dampak globalisasi sebagai akibat perkembangan IPTEK. Bertolak pada pendapat Muladi (2007:30) yang mengatakan bahwa Pancasila merupakan filter dalam mentransformasikan nilainilai global dalam kehidupan nasional karena globalisasi tidak dapat diterima secara bulat. Oleh sebab itu, filter tersebut diperlukan karena tidak semua perkembangan yang ada dapat diterima atau dapat diterapkan dalam kehidupan bangsa Indonesia.

Sebagai pandangan hidup, Pancasila merupakan kristalisasi dari nilai-nilai yang hidup dan yang diyakini kebnarannya oleh bangsa Indonesia dan menjadi pedoman bertingkah laku dalam berbangsa dan bernegara. Berdasar pada Pancasila sebagai pandangan hidup bangsa Indonesia, maka menjadi suatu keniscayaan bahwa Pancasila merupakan dasar dalam pembangunan hukum nasional.

Sebagai dasar negara, Pancasila merupakan hukum dasar bagi negara di mana segala sesuatu yang berhubungan dengan kehidupan ketatanegaraan Republik Indonesia harus berdasarkan Pancasila. Hal tersebut mengandung makna bahwa semua peraturan yang berlaku di negara republik Indonesia harus bersumber pada Pancasila. Dengan kata lain 
Pancasila adalah sumber segala sumber hukum bagi bangsa dan negara Indonesia. Oleh sebab itu, semua tindakan kekuasaan atau kekuatan dalam masyarakat harus berdasarkan pada peraturan hukum yang bersumber pada Pancasila (Darji Darmodiharjo, 1991: 19).

Sebagai negara hukum, maka Indonesia menjadikan hukum sebagai norma di dalam negara, di mana hukumhukum tersebut seharusnya dibentuk dengan berdasarkan pada Pancasila, karena sebagai alat yang berfungsi untuk menciptakan tata dalam masyarakat, maka hukum harus dibentuk dengan berdasar pada ideologi bangsa yang menjadi cita-cita bangsa (Sudarto, 1972:88).

Keharusan hukum berdasar pada Pancasila sebagai ideologi bangsa adalah karena ideologi bangsa merupakan dasar filsafat Negara (Kaelan, 2002:59). Hal ini menunjukkan bahwa sesungguhnya hukum tidak dapat begitu saja ditransformasikan dari negara satu ke negara yang lainnya, karena hukum suatu bangsa adalah cerminan nilai dan moral bangsa yang bersangkutan (Suteki, 2007:1). Hukum dapat ditegakkan apabila hukum tersebut sesuai dengan nilai-nilai bangsa itu sendiri (Satjipto Rahardjo, 2008:32). Jadi hukum yang efektif adalah hukum yang berdasarkan pada nilai-nilai dari bangsa tersebut.

Di samping ketentuan yang ada sudah menggariskan bahwa politik hukum bangsa Indonesia berdasarkan pada Pancasila yang memuat nilai-nilai agama, hukum yang hidup dan keyakinan bangsa, para sarjana berualang kali menegaskan di berbagai forum seminar hukum nasional, agar dalam melakukan Pembaharuan Sistem Hukum Nasionaldigunakan pendekatan religius yang dikaitkan juga dengan pendekatan nilai-nilai budaya dan kesadaran hukum yang hidup dalam masyarakat (hukum adat).

Digunakannya pendekatan kultural-religius dalam pembangunan hukum nasional ditegaskan dalam Simposium "Pengaruh Kebudayaan/Agama terhadap Hukum Pidana Khusus" 1975. Di mana dalam Kesimpulan Komisi I antara lain dikemukakan bahwa "Dalam menetapkan delik-delik susila supaya diperhatikan faktorfaktor agama, adat serta modernisasi dan dalam penerapannya diperhitungkan nilai-nilai umum yang berlaku dalam masyarakat". Dari hasil simposium tersebut 
secara jelas dapat ditarik kesimpulan bahwa di dalam melakukan rekonstruksi kebijakan reformulasi delik kesusilaan (termasuk di dalamnya delik perzinahan) agar mengakomodasi nilai-nilai yang hidup dalam masyarakat, nilai-nilai agama serta modernisasi atau perkembangan teknologi.

Sebagaimana yang kita ketahui bahwa semua nilainilai yang hidup dalam masyarakat dan nilai-nilai agama yang ada di Indonesia sudah terkristalisasi dalam sila-sila Pancasila. Oleh sebab itu dalam melakukan rekonstruksi kebijakan formulasi delik perzinahan harus berdasar pada nilai-nilai Pancasila. Himbauan agar pembangunan sistem hukum nasional hendaknya berdasarkan pada nilai-nilai Pancasila dapat dilihat besarnya perhatian seminar-seminar hukum nasional yang menghasilkan beberapa rekomendasi terkait dengan hal tersebut, antara lain (Barda Nawawi Arief,2009:1-120);

1. Seminar Hukum Nasional I tahun 1963 :

Pokok-pokok ajaran hukum Indonesia dan bentuk hukum Nasional : dasar pokok hukum nasional Republik Indonesia adalah Pancasila.

2. Seminar Hukum nasional II tahun 1968 :

UUD 1945 hanyalah boleh dilaksanakan atas dasar Pancasila. Pelaksanaan UUD 1945 yang berlawanan dengan semangat dan jiwa Pancasila berarti manipulasi konstitusi dan pengkhanatan terhadap Pancasila. Berhubung dengan itu diperlukan konsepsi pelaksanaan Pancasila dalam segala bidang kehidupan (politik, hukum, ekonomi, sosial, budaya).

3. Seminar Hukum Nasional III tahun 1974 :

Dasar pembinaan Hukum Nasional adalah Pancasila, UUD 1945 dan GBHN

4. Seminar Hukum Nasional IV tahun 1979:

B. Sistem Hukum Nasional

1. Pencerminan nilai-nilai Pancasila dalam Perundang-undangan.

a. Pancasila yang mengandung nilai-nilai kejiwaan bangsa Indonesia merupakan dasar tertib hukum Indonesia, pedoman dan penunjuk arah perkembangannya dengan sistem yang terbuka dan adalah batu ujian 
Any Ismayawati

mengenai kepatutan dan perundangundangan.

b. Dalam menyusun undang-undang, pembentuk undang-undang perlu dengan tepat menunjukkan nilai-nilai Pancasila, yang mendasari ketentuan undang-undang itu. Dengan demikian peraturan-peraturan hukum merupakan pelaksanaan undang-undang itu tidak boleh mengandung hal-hal yang bertentangan dengan Pancasila.

c. Pencerminan nilai-nilai Pancasila di dalam perundang-undangan merupakan hakikat pembentukan sistem hukum nasional.

5. Seminar Hukum Nasional V tahun 1990 :

Mukaddimah Hasil Seminar :

1. Dalam Repelita V dengan tegas dinyatakan bahwa perlu dimantapkan lagi kerangka landasan hukum serta asas-asas tata hukum Nasional Indonesia yang berjiwakan Pancasila dan UUD 1945 yang telah diletakkan dalam Repelita IV.

Saran Hasil Perumusan Sidang Kelompok VC :

pada akhir Repelita VI sudah harus tersusun pola pikir dan kerangka sistem hukum nasional berdasarkan Pancasila dan UUD 1945.

6. Seminar Hukum Nasional VI tahun 1994 :

- Sistem hukum nasional yang juga merupakan sistem hukum Pancasila harus merupakan penjabaran dari seluruh sila-sila Pancasila secara keseluruhan.

- Hukum suatu bangsa bersifat "bangsa sentris" oleh karena itu wajar bilamana bangsa Indonesia mengajarkan "sistem hukum Pancasila" (SHP) untuk menggambarkan karakteristiknya.

- Perlu untuk dikembangkan gagasan mengenai kualitas pemberian keadilan (the dispensionsof justice) yang lebih cocok dengan sistem hukum Pancasila.

- Pengembangan sistem hukum Pancasila tdak hanya memerlukan dukungan dari pemerintah yang bersih dan berwibawa tetapi juga oleh 
pemerintah yang "baik hati" yang didasarkan pada supremasi moral.

Rekomendasi Khusus :

1. Kedudukan Pancasila sebagai sumber dari segala sumber hukum, perlu dimasyarakatkan.

Seminar Hukum Nasional I sampai dengan VI, secara tersurat menyebutkan bahwa sistem hukum nasional yang hendak dibangun adalah Sistem Hukum Pancasila. Sedangkan dalam Seminar Hukum Nasional VII dan VIII secara tersirat juga menetapkan bahwa yang hendak dibangun adalah Sistem Hukum Pancasila. Hasil seminar tersebut mengandung arti bahwa setiap pembaharuan/pembangunan hukum di Indonesia harus berdasar pada nilai-nilai Pancasila. Hal yang tidak dapat ditawar lagi bahwa Pancasila adalah rechstidee dalam membentuk undang-undang yang mengatur kehidupan berbangsa dan bernegara bagi masyarakat Indonesia.

Di dalam hasil kesimpulan dan rekomendasi Konvensi Hukum Nasional 2008 tentang Undang Undang Dasar 1945 sebagai Landasan Konstitusional Grand Design Sistem dan Politik Hukum Nasional, secara tersirat maupun tersurat juga menyebutkan bahwa sistem dan politik hukum nasional berlandaskan Pancasila. Disimpulkan pula bahwa dalam pembentukan Grand Design Sistem dan Politik Hukum Nasional harus secara konsisten didasari landasan falsafah Pancasila (Barda Nawawi Arief, 2009: 121-123).

Di samping beberapa hasil seminar nasional dan konvensi hukum nasional yang merekomendasikan Pancasila sebagai bentuk dan dasar sistem hukum nasional, ada beberapa pendapat para tokoh yang menjadikan Pancasila sebagai dasar sistem hukum nasional, yang menunjukkan bahwa pembangunan sistem hukum nasional dengan berdasarkan Pancasila adalah sebuah keniscayaan. Pendapat tokoh tersebut antara lain datang dari Hazairin dalam konferensi Departemen Kehakiman tahun 1950, mengatakan :"................Pancasilalah yang paling tepat untuk dijadikan rujukan bagi segala hukum di Indonesia karena Pancasila adalah dasar dan falsafah kenegaraan dari bangsa Indonesia. Dan di atas demokrasi Pancasila masih ada suatu kedaulatan yang harus diperhatikan, yaitu kedaulatan Allah SWT, yang disebut Ketuhanan yang Maha 
Esa dalam sila pertama dari Pancasila. Kalau kita ingin membentuk hukum, maka kita harus berpegang teguh kepada ajaran kedaulatan Tuhan itu" (Hazairin dalam Abdul Manan, 2007: 237-238).

Ismail saleh (1987: 38-39) mengatakan "apabila hendak membentuk dan melaksanakan norma-norma hukum yang berfungsi mengatur tata hubungan antara seseorang dan sesamanya serta antara seseorang dengan masyarakat dan negaranya, maka harus selalu menempatkan Pancasila sebagai mata hati nurani kita". Dikatakan pula oleh beliau bahwa "Pancasila selain merupakan cita hukum juga merupakan norma dasar negara. Karenanya Pancasila di samping sebagai "pengarah" dan "pemandu" bekerjanya seluruh sistem hukum nasional, juga merupakan norma hukum yang paling tinggi, tempat berkaitnya seluruh norma kenegaraan dan kemasyarakatan". Berdasarkan beberapa pendapat tersebut, maka tidak dapat dibenarkan apabila ada aturan hukum yang bertentangan dengan nilai-nilai Pancasila. Dengan kata lain apabila ada aturan hukum yang tidak sesuai dengan Pancasila harus segera dilakukan rekonstruksi

Penggunaan Pancasila sebagai hukum dasar dalam pembangunan hukum nasional, dapat dilihat antara lain dalam ketentuan-ketentuan tersebut di bawah ini yaitu:

1. UU Nomor 1 Drt 1951 di dalam Pasal 5 ayat (3) sub b yang menyatakan sebagai berikut :

- Bahwa suatu perbuatan yang menurut hukum yang hidup harus dianggap perbuatan pidana, akan tetapi tiada bandingannya dalam Kitab Hukum Pidana sipil, maka dianggap diancam dengan hukuman yang tidak lebih dari tiga bulan penjara atau denda lima ratus rupiah, yaitu sebagai hukuman pengganti bilamana hukuman adat yang dijatuhkan tidak diikuti oleh pihak yang terhukum dan penggantian yang dimaksud dianggap sepadan oleh hakim dengan besar kesalahan terhukum;

- Bahwa suatu perbuatan yang menurut hukum yang hidup harus dianggap perbuatan pidana dan yang ada bandingannya dalam Kitab Hukum Pidana Sipil, maka dianggap diancam dengan hukuman yang sama dengan hukuman bandingannya yang paling mirip 
kepada perbuatan pidana itu (Barda Nawawi Arief , 2006: 5).

2. UU Kekuasaan Kehakiman Nomer 14 Tahun 1970

- Pasal 23 ayat (1) : "segala putusan pengadilan selain harus memuat alasan-alasan dan dasar-dasar putusan itu, juga harus memuat pula pasal-pasal tertentu dari peraturan-peraturan yang bersangkutan atau sumber hukum tidak tertulis".

- Pasal 27 ayat (1) : “Hakim sebagai penegak hukum dan keadilan, wajib menggali, mengikuti dan memahami nilai-nilai hukum yang hidup".

3. UU Kekuasaan Kehakiman Nomer 4 Tahun 2004

- Pasal 25 ayat (1) : "segala putusan pengadilan selain harus memuat alasan dan dasar putusan tersebut, memuat pula pasal tertentu dari peraturan yang bersangkutan atau sumber hukum tidak tertulis yang dijadikan dasar untuk mengadili"

- Pasal 28 ayat (1) : “Hakim wajib menggali, mengikuti dan memahami nilai-nilai hukum dan rasa keadilan yang hidup dalam masyarakat".

4. Pasal 5 (1) UU No.48/2009 : Hakim dan hakim konstitusi wajib menggali, mengikuti, dan memahami nilai-nilai hukum dan rasa keadilan yang hidup dalam masyarakat

5. Pasal 18 B (2) UUD 1945 (Amandemen ke-4) :

Negara mengakui dan menghormati kesatuankesatuan masyarakat hukum adat beserta hak-hak tradisionalnya sepanjang masih hidup dan sesuai dengan perkembangan masyarakat dan prinsip Negara Kesatuan Republik Indonesia, yang diatur dalam undang-undang (Barda Nawawi Arief, 2006: 5)

Bertolak pada beberapa peraturan sebagaimana tersebut di atas, maka dalam rekonstruksi hukum pidana nasional digunakan pendekatan kebijakan dan pendekatan nilai.Menjadi sebuah keharusan kalau nilai-nilai Pancasila menjadi ide dasar dan arah tujuan dalam pembaharuan Hukum Nasional, karena Pancasila merupakan kristalisasi dari nilai-nilai yang sesuai dengan jiwa dan kepribadian bangsa Indonesia serta diyakini kebenarannya. Oleh sebab itu dalam pembaharuan hukum pidana, nilai-nilai Pancasila 
harus merasuk di dalam seluruh nafas pasal-pasalnya. Hukum Pidana Nasioanal mendatang, harus secara sadar disusun dalam kerangka Ideologi Nasional Pancasila (Muladi, 1990: 149).

Sebagaimana yang tertuang dalam Pasal 2 ayat (2) UU Nomor 48 Tahun 2009 Tentang Kekuasaan Kehakiman yang menyebutkan bahwa "Peradilan negara menerapkan dan menegakkan hukum dan keadilan berdasarkan Pancasila".Bunyi pasal tersebut tentunya dilandasi pemikiran bahwa hukum akan dapat ditegakkan dan akan efektif apabila bersumber pada nilai-nilai yang hidup dan diyakini kebenarannya oleh bangsa Indonesia, sedangkan Pancasila merupakan wujud konkrit dari nilai-nilai yang hidup di dalam masyarakat Indonesia.

Demikian pula halnya dalam Undang-undang Nomor 10 tahun 2004 tentang Pembentukan Peraturan Perundangundangan, di mana dalam Pasal 2 secara eksplisit disebutkan bahwa Pancasila merupakan sumber dari segala sumber hukum negara. Dapat dikatakan Pasal 2 tersebut merupakan landasan yuridis digunakannya Pancasila sebagai landasan iidiil dalam pembentukan perundangundangan. Undang-undang ini diperbaharui dengan Undang-undang Nomor 12 tahun 2011 tentang Pembentukan Peraturan Perundang-undangan. Undangundang yang baru ini tetap menjadikan Pancasila sebagai sumber segala sumber hukum negara sebagaimana yang tertuang di dalam Pasal 2. Di dalam penjelasan Pasal 2 disebutkan bahwa dengan menjadikan Pancasila sebagai suumber segala sumber hukum, terkandung maksud menempatkan Pancasila sebagai dasar dan ideologi negara serta sekaligus dasar filosofis negara sehingga setiap materi muatan peraturan perundang-undangan tidak boleh bertentangan dengan nilai-nilai yang terkandung dalam Pancasila. Berdasarkan penjelasan undang-undang tersebut menunjukkan bahwa di dalam negara Indonesia tidak diperbolehkan adanya suatu peraturan perundangan yang bertentangan dengan nilai-nilai yang terkandung dalam silasila Pancasila. Bertolak pada hal tersebut maka Undangundang Nomor 10 tahun 2004 tentang Pembentukan Peraturan Perundang-undangan yang kemudian disempurnakan dengan Undang-undang Nomor 12 tahun 
2011 tentang Pembentukan Peraturan Perundang-undangan merupakan landasan yuridis keharusan penggunaan Pancasila sebagai basic ideas dalam pembangunan hukum.

\section{Kesimpulan}

Pada dasarnya pembangunan hukum nasional adalah melakukan rekonstruksi hukum agar sesuai dengan jiwa atau kepribadian bangsa Indonesia, serta dalam upaya mengikuti perkembangan masyarakat dan IPTEK. Oleh sebab itu pembangunan hukum nasional seharusnya mendasarkan pada nilai-nilai yang hidup dalam masyarakat, yang diyakini kebenarannya dan mengikat masyarakat, artinya menjadipetunjuk dalam berkehidupan.Bertolak pada hal tersebut, maka dalam melakukan pembangunan hukum nasional harus berdasar pada asas-asas yang ada dalam nilai-nilai Pancaila karena nilai-nilai Pancasila sesungguhnya adalah kristalisasi dari nilai-nilai agama dan nilai-nilai adat yang diyakini kebenarannya oleh bangsa Indonesia dan menjadi petunjuk hidup. 
Any Ismayawati

\section{Daftar Pustaka}

Bakry, Noor MS, 1994, Pancasila Yuridis Kenegaraan,Liberty, Yogyakarta

Darmodihardjo, Dardji, Pokok-pokok Hasil Penelitian tentang Nilai-nilai Pancasila sebagai Nilai Dasar Pengembangan Ilmu Hukum Indonesia, Tim Peneliti Fakultas Hukum UGM dan Fakultas Hukum Universitas Pancasila, dipresentasikan dalam Seminar Nasional "Nilainilai Pancasila sebagai Nilai Dasar Pengembangan Ilmu Hukum Indonesia" dalam rangka Dies Natalis Universitas Pancasila ke 40. Diselenggarakan oleh Fakultas Hukum Universitas Pancasila pada tanggal 7 Desember 2007

Darmodiharjo, Darji, Orientasi Singkat Pancasila, dalam Santiaji Pancasila Suatu Tinjauan Filosofis, Historis dan Yuridis Konstitusional, Surabaya : Usaha Nasional, 1991

Hazairin dalam Abdul Manan, Etika Hakim Dalam Penyelenggaraan Peradilan, Suatu Kajian Dalam Sistem Peradilan Islam, Jakarta : Kencana Prenada Media Group, 2007

Kaelan, Filsafat Pancasila Pandangan Hidup Bangsa, Yogyakarta : Paradigma, 2002

Kaelan, Filsafat Pancasila, Yogyakarta : Paradigma, 1996

M. Mahfud MD dalam Membangun Politik Hukum menegakkan Konstitusi, Jakarta : Pustaka LP3ES, 2006

Mansyur, M.Ali, Pancasila Sebagai Dasar Pengembangan Ilmu Hukum Indonesia, Jurnal Hukum, Vol.XV No.1, Juni 2005

Moeljatno, Fungsi dan Tujuan Hukum Pidana Indonesia, Jakarta : Bina Aksara, 1985

Muladi, Pancasila Sebagai Dasar Pengembangan Ilmu Hukum Indonesia, Pidato utama pada Seminar Nasional "Nilai-nilai Pancasila sebagai Nilai Dasar Pengembangan Ilmu Hukum Indonesia" dalam rangka Dies Natalis Universitas Pancasila ke 40. Diselenggarakan oleh Fakultas Hukum Universitas Pancasila pada tanggal 7 Desember 2007

Nawawi Arief, Barda,Beberapa Aspek Pengembangan Ilmu Hukum Pidana (Menyongsong Generasi Baru Hukum 
Pidana Indonesia, Pidato Pengukuhan Guru Besar Fakultas Hukum Undip, Semarang, 25 Juni 1994

--------, Pembaharuan Hukum Pidana Dalam Perspektif Kajian Perbandingan, Bandung: Citra Aditya Bakti, 2005

--_---, Perkembangan Azas-azas Hukum Pidana dalam Konsep KUHP (Perspektif Hukum Perbandingan Hukum Pidana), Makalah dalam Penataran Regional Hukum Pidana dan Kriminologi, UNDIP, April 2006

-------, Kumpulan Hasil Seminar Hukum Nasional ke I s/d VIII dan Konvensi Hukum Nasional 2008, Semarang : Pustaka Magister Semarang, 2009

-------, Pembangunan Sistem Hukum Nasional Indonesia, Kuliah Umum pada Program Magister Ilmu Hukum, Pascasarjana UBH, Padang, 16 Mei 2009

------, Pendekatan Keilmuan dan Pendekatan Religius dalam rangka Optimalisasi dan Reformasi Penegakan Hukum (Pidana) di Indonesia, Semarang : Badan Penerbit Undip, 2011

Poespowardojo, Soerjanto, Pancasila Sebagai Ideologi Ditinjau dari Segi Pandangan Hidup Bersama, dalam "Pancasila Sebagai Ideologi dalam Berbagai Bidang Kehidupan Bermasyarakat, Berbangsa dan Bernegara, BP-7 Pusat, Jakarta : Percetakan Negara RI, 1996

Rahardjo, Satjipto,Membangun dan Merombak Hukum Indonesia Sebuah Pendekatan Lintas Disiplin, Jakarta : Genta Publishing, 2009

Saleh, Ismail, Kebijaksanaan dan Strategi Pembangunan dan Pembinaan Hukum Nasional, Beserta Implementasinya, Jakarta : Departemen Kehakiman Republik Indonesia, 1987

Saleh, Roeslan, Segi Lain Hukum Pidana, Jakarta : Ghalia indonesia, 1984

Sudarto, Hukum dan Hukum Pidana, Bandung : Alumni, 1972 , Hukum Pidana dan Perkembangan Masyarakat Kajian terhadap Pembaharuan Hukum Pidana, Bandung : Sinar Baru, 1983

Sudharta, B. Arief, Filsafat Hukum Pancasila, Seminar Nasional "Nilai-nilai Pancasila sebagai Nilai Dasar Pengembangan Ilmu Hukum Indonesia" dalam rangka Dies Natalis Universitas Pancasila ke 40. 
Any Ismayawati

Diselenggarakan oleh Fakultas Hukum Universitas Pancasila pada tanggal 7 Desember 2007

Sudjito, Pancasila Sebagai dasar Filsafat dan Paradigma Ilmu Hukum, disampaikan dalam matrikulasi Program Doktor Ilmu Hukum UNS, tanggal 02 Maret 2013

Suteki, Integrasi Hukum dan Masyarakat, Semarang : Pustaka Magister 2007

Sutrisno, Endang, Bunga Rampai Hukum dan Globalisasi, Yogyakarta : Genta Press, 2009

Tamanaha, Brian Z., A General Jurisprudence of Law and Society, Oxford : OxfordUniversity Press, 2006

Wibisono Siswomihrdjo, Koento, Pemantapan Nilai-nilai Pancasila sebagai Dasar Pengembangan Ilmu Hukum dalam Kerangka Sistem Kenegaraan Indonesia.

\section{Perundang-undangan :}

Undang-Undang Dasar Negara Republik Indonesia Tahun 1945

Undang-undang Nomor 12 Tahun 2011 Tentang Pembentukan Peraturan Perundang-undangan 